\title{
Statistics with Project-Based Learning in Junior High School
}

\author{
Iyam Maryati ${ }^{1}$, Sri Adi Widodo ${ }^{2}$ \\ \{iyammaryati81@gmail.com, sriadi@ustjogja.ac.id\} \\ Institut Pendidikan Indonesia, Garut Indonesia ${ }^{1}$ \\ Universitas Sarjanawiyata Tamansiswa, Yogyakarta, Indonesia ${ }^{2}$
}

\begin{abstract}
This article is literature study which aims to describe the Project-Based Learning Model that is applied in statistical materials for students in Grade VIII junior high school. In this article also presents a Learning Implementation Plan as an alternative in the implementation of learning. Based on the review of literature from relevant research, it was found that the ability of literacy and statistical reasoning for both students were still in the low category. This happens because it is strongly influenced by the learning model applied. In this project-based learning model the teacher is given the opportunity to do learning that involves project work. The end result of the project work can be in the form of reports and presentations. The project assignment assessment begins with the process of planning, implementing, and ending project tasks. Therefore, the project-based learning model can be used as an alternative in learning.
\end{abstract}

Keywords: Project Based Learning; Statistical.

\section{Introduction}

In building a community order in a nation lies in the quality of human resources. To build good quality human resources it will not materialize except with education. So that education has a very important and strategic role in building a knowledgeable society. In the 21 st century competition in various fields of life is increasingly competitive. Therefore, the education applied must form learning skills that can compete in overcoming the problems faced. One of the ways that must be pursued is by improving the quality of education [1].

The characteristics of learning in education unit are closely related to the Competency Standards of Graduates and Content Standards. Graduate competency standards provide a conceptual framework for learning objectives that must be achieved, the content standard provides a conceptual framework for learning and learning activities derived from the level of competence and the scope of the material [2]. Learning objectives include developing the realm of attitudes, knowledge, and skills that are elaborated for each education unit. Likewise an educator to assess skills competency through performance appraisal is an assessment that requires students to demonstrate certain abilities by using practice tests, projects, and portofolio assessments [3]. An assessment that requires students to demonstrate a particular competency by using practice, project and portfolio assessment tests. For project appraisals conducted by an educator, still according to the assessment Standard is carried out at the end of each chapter or theme of the lesson. 
The results of a preliminary study on 35 junior high school students in Garut, shows that the statistical literacy ability is $35 \%$ students are able to read statistical data given in tables, diagrams and graphs; $32 \%$ ability in understanding concepts; $30 \%$ ability in communicating data processing; and $28 \%$ ability in presenting data processing results. Student in Junior High school show that literacy skills of data starting from paying attention to the graphic title and then digging up the information presented in the graph. In interpreting and concluding data, students pay attention to general patterns and data fluctuations and use general data trends to predict data [4]. While the mathematical literacy skills of prospective math teacher students showed that 3 students used as research subjects were at level 4 form 6 and even then it happened to subjects with very good Mathematical abilities [5], the same results also show that, $65.7 \%$ of students were able to understand the problems and plan their strategies to solve them. Meanwhile, only $46.9 \%$ among them could answer correctly. In addition, only $36.8 \%$ of the students were able to understand the level 6 problems while only $23.7 \%$ among them answered correctly [6]. In addition, 32 other junior high school students in Garut showed that the mean value of misconception test was 49.7 and the standard deviation was 10.6 while the mean value of statistical reasoning skill test was 51.8 and standard deviation was 8.5. If the minimum value is 65 to state the standard achievement of a course competence, students' mean value is lower than the standard competence [7].

From the results of these studies, students' literacy skills in statistical material, statistical reasoning, and mathematical literacy are strongly influenced by the learning model applied by the teacher. So the purpose of this article is to examine the relationship between project based learning and statistical literacy skills. Project-based learning model is very suitable to be applied in understanding statistical material. This is stated in the module Model of Learning Mathematics, Statistics and Opportunities (Project Based Learning (PBL) is a learning model that involves students in an activity (project) that produces a product. The involvement of students ranging from planning, drafting, implementing and report the results of activities in the form of products and their implementation reports. This learning model emphasizes the longterm learning process, students are directly involved with various issues and issues of daily life, learn how to understand and resolve real problems, and are interdisciplinary.

\section{Method}

This study was a preliminary research and did not intend to model of learning, but only did a conceptual approach prior to a research development. So, the main method carried out was to compare the various literature related to project based learning, and literacy of statistical.

\section{Result and Discussion}

\subsection{Project Based Learning}

In rational changes to the Curriculum of 2006 into curriculum of 2013 stated that the development of knowledge and pedagogy in this case neurology, psychology, observation based learning and collaborative learning is one reason for the importance of curriculum changes. This certainly has implications for learning models used in teaching activities in schools. One of the recommended learning models to be used is a project-based learning model. This is certainly 
not without reason, because considering there are superior characteristics of this learning model that can accommodate these reasons.

Project Based Learning is one of the learning models that can be used by the teacher so that the teacher automatically uses the scientific approach in learning. The scientific approach is a learning approach in which students acquire knowledge based on scientific work. Through this scientific approach, students will be invited to pursue a golden bridge so that they not only gain knowledge but will also get the skills and attitudes needed in their future lives. When learning to use this project-based learning model, students can practice inductive reasoning. As one of the learning models in the scientific approach, project based learning is very in accordance with Permendikbud Number 81 A of 2013 Attachment IV concerning the learning process that must contain 5M namely observing, asking, collecting information, associate, and communicating [7].

In this project-based learning model, students do active learning. They really will be active both hands on through physical activities, and minds on through thinking or mentally activities. Because of this, the spirit of implementing this project-based learning model is in full accordance with the mandate of the 2013 Curriculum. Students, through active learning, will carry out 5M activities (observing, asking questions, gathering information, associating, and communicating).

In its implementation, the project-based learning model has steps that become its trademark and distinguishes it from other learning models such as discovery learning models and problem based learning models. The steps are determine basic questions, making project designs, scheduling, monitor project progress, assessment of results, experience evaluation.

Project-based learning models always begin by finding out what are the fundamental questions, which will become the basis for providing project assignments for students (doing activities). Of course the topic used must also relate to the real world. Next with the help of the teacher, groups of students will design activities that will be carried out on their respective projects. The greater the involvement and ideas of students (student groups) used in the project, the greater their sense of ownership of the project. Furthermore, the teacher and students determine the time limit given in the completion of the task (activity) of their project.

Over time, students carry out all activities starting from the preparation of their project implementation to reporting it while the teacher monitors and monitors the progress of student group projects and provides the necessary guidance. In the next stage, after students report the results of the project they are doing, the teacher assesses the achievements that students get both in terms of knowledge (knowledge related to concepts relevant to the topic), to the skills and attitudes that accompany them. Finally, the teacher then provides the opportunity for students to reflect on all activities (activities) in project-based learning that they have done so that the opportunities for learning and project completion activities will be even better.

Steps for implementing project-based learning are first start with the essential question. learning begins with an essential question which is a question that can give assignments to students in carrying out an activity. The assignment topic is in accordance with the real world that is relevant to students, and begins with an in-depth investigation. Second, design a plan for the project. Planning is done collaboratively between teachers and students. Thus students are expected to feel "possessed" of the project. Planning is about the rules of the game, the selection of activities that can support in answering essential questions, by integrating various possible subjects, and knowing the tools and materials that can be accessed to help with project completion. Third, Create a Schedule. Teachers and students collaboratively arrange a schedule of activities in completing the project. Activities at this stage include: (1) creating a timeline (time allocation) to complete the project, (2) making deadlines (final deadline) of project 
completion, (3) bringing students to plan new ways, (4) guiding participants students when they make ways that are not related to the project, and (5) ask students to make an explanation (reason) about the election. Fourth, monitor the students and the progress of the project. The teacher is responsible for monitoring the activities of students during project completion. Monitoring is done by facilitating students in each process. In other words the teacher acts as a mentor for student activities. In order to facilitate the monitoring process, a rubric is created that can record all important activities. Fifth, assess the outcome. Assessment is carried out to assist teachers in measuring standard achievement, play a role in evaluating the progress of each student, giving feedback about the level of understanding that has been achieved by students, helping the teacher in developing the next learning strategy. Sixth, Evaluate the experience. At the end of the lesson, the teacher and students reflect on the activities and results of the project that has been carried out. The reflection process is carried out both individually and in groups.

Project assignment assessment Project appraisal is an assessment of an assignment that must be completed within a certain period or time. The task is in the form of an investigation or investigation from planning, data collection, organizing, processing and presenting data. Project appraisal can be used to find out the understanding, the ability to apply, the ability to investigate and the ability of students to provide information about something that becomes clearly investigated on certain material. In the assessment of the project, there are a few things to note are management ability (the ability of choose a topic if it has not been determined by the teacher, find information and manage the time of data collection and report writing), The relevance is conformity with the subject by considering the stage of knowledge, understanding and skills in learning, and authenticity the project carried out by the student must be the result of his work, taking into account the teacher's contribution in the form of instructions and support for student projects [8].

Project-based learning, the problem is defined by challenges that can be solved by project design, stages of project stages [9] . In other words, the problem in the project-based learning model is the purpose of the project. The advantages of project-based learning are: increasing student learning motivation, improving problem solving skills, increasing collaboration, and improving resource management skills that are responsible for completing complex tasks [10].

\subsection{Application of Project-Based Learning Models in Statistical Materials}

As one example The application of a project-based learning model on statistical material in class VIII was carried out in four meetings (identic with 10 hours of lessons) in achieving core competencies analyzing data based on data distribution, mean value, median, mode, and data distribution to draw conclusions, make decisions, and make predictions. As well as competence presents and resolves problems related to data distribution, average value, median, mode, and distribution of data to draw conclusions, make decisions, and make predictions.

Through the learning process of statistical material, students have the following learning experiences (a) sort single data using a bar-leaf diagram, (b) presenting data with a single data frequency distribution table and group data, (c) calculate the mean, mode, and median and explain their meaning, (d) calculates data coverage, quartiles, and interquartile reach of single data and explains their meaning.

To achieve the learning experience, 5 meetings are needed that is first is to teach students with the learning syntax of observing, asking, collecting information, associating, and communicating related material. Calculating the mean (average), mode and median and explaining their meaning. Second is to teach students with the learning syntax of observing, questioning, collecting information, associating, and communicating related material. Calculating data coverage, quartiles, and interquartile reach of a single data and explaining its 
meaning. Third 3 is to apply a project-based learning model with the syntax of Determining Fundamental Questions (Start with the Essential Question), Designing Project Planning (Design a Plan for the Project), Arranging Schedules (Create a Schedule). Fourth is to implement a project-based learning model with the syntax of monitoring students and project progress (Monitor the Students and the Progress of the Project), Assessing Outcome. Fifth is evaluating learning experiences.

Examples of project design/ completion plans with descriptions of activities as follows gather information from various sources, finding or observing or investigating objects that are around to be used as data, write notes and group data obtained, communication with teachers related to the activities that have been carried out, make a report in the form of exposure or presentation, presentation preparation or equipment checking, presentation, record comments and suggestions from friends and teachers.

Examples of the application of project-based learning model syntax that is first phase: Determination of Fundamental Question, second phase: designing Project Planning, third phase: arrange a schedule, fourth phase: monitor Students and Project progress, and fifth phase: testing result evaluating experience. In first phase covering (1) learning activities carried out: The teacher encourages students to ask essential questions, namely questions that can give assignments to students in carrying out an activity. (2) The topic of assignment is in accordance with the real world that is relevant to students and starts with an in-depth investigation. For example students examine the data of classmates about shoe size, height, number of daily allowances, library visitors, class absences, test scores, and so on. In second phase, learning activities carried out students collaboratively do project planning design, students are expected to feel ownership of the project, planning contains rules of the game, selection of activities that can support in answering essential questions, integrating possible subjects, and knowing the tools and materials that can be accessed to assist in the completion of the project.

In third phase, Learning activities carried out: students compile a timeline to complete the project, make deadlines for project completion, direct students to plan new ways, students choose teaching aids that support project completion related to data centering and data dissemination, ask students to make an explanation about the choice of solution in solving the given problem. In fourth phase covering the teacher is responsible for monitoring the activities of students during project completion, teacher conducts monitoring by facilitating students in each process, teacher acts as a mentor for the activities of the person, and teacher makes a rubric that can record all important activities. In last phase is testing Results Evaluating Experience covering teacher evaluates to measure standard achievement, teacher plays a role in evaluating the progress of each student, teacher gives feedback about the level of understanding students have achieved, and Teachers receive various inputs in developing the next learning strategy. Examples of project worksheets in statistical material:

Determine the average weight.

First, students make groups of 5-6 students. Then each group conducts measurement and data calculation activities as follows each group member and group chairperson weighs each body's weight in the school health room. Each measurement is done twice to make it more accurate, one member of each group records the results of the measurement, each group discusses to determine the mean value (mean) of student weight in the group, and each group presents the results of the discussion in front of the class.

Determine the mode and median values by collecting data.

First, students are grouped into 4 groups. Then each group conducts data collection activities as follows the chairperson of the group collects data about the number of shoes worn by its members, the secretary records the data, each group discuss how a practical way to 
determine the mode of the student shoe number data, and each group presents the results of the discussion in front of the class.

\section{Conclusion}

To strengthen the integrated (thematic between subjects) scientific and thematic approaches, and thematic (in a subject) it is necessary to apply disclosure /research learning. In order for students to produce contextual work both individually and in groups, it is strongly recommended to use a learning approach that produces project-based learning. Likewise in Permendikbud Number 66 of 2013 concerning assessment standards said that an educator to assess skills competency through performance appraisal is an assessment that requires students to demonstrate a particular competency by using practice, project and portfolio assessment tests. For project assessments carried out by an educator, according to the assessment Standard is carried out at the end of each chapter or theme of the lesson.

Project-based learning is a learning model that provides opportunities for teachers to manage learning in the classroom by involving project work. Project work contains complex tasks based on very challenging problems (problems), and requires students to do activities to design, solve problems, make decisions, conduct investigative activities, and provide opportunities for students to work independently or in groups. The result of the project work is a product, which includes written reports, presentations or recommendations.

\section{References}

[1] "21st Century Skills , Education \& Competitiveness: A Resource and Policy Guide," Tucson, 2018.

[2] Permendikbud No 65. 2013.

[3] "Permendikbud No 66," 2013.

[4] M. Hafiyusholeh, "Literasi Statistik dan Urgensinya Bagi Siswa," Wahana, vol. 64, no. 1 , pp. 1-8, 2015.

[5] M. N. Prabawati, "Analisis Kemampuan Literasi Matematik MAhasiswa Calon Guru Matematika," Mosharofa, vol. 7, no. 1, pp. 25-34, 2017.

[6] A. Istiandaru, N. Syakrina, F. Setyawan, R. Charitas, I. Prahmana, A. Sofyan, and E. Hidayat, "How Students Solves PISA Tasks : An Overview of Students ' Mathematical Literacy," vol. 2, no. 2, pp. 129-138, 2018.

[7] Kemdikbud, Materi Pelatihan Guru Implementasi Kurikulum 2013 SMP/MTs Matematika. Jakarta: BPSDMP \& PMP Kemdikbud, 2013.

[8] T. Widyantini, "Penerapan Model Project Based Learning (Model Pembelajaran Berbasis Proyek) dalam Materi Pola Bilangan Kelas VII,” Yogyakarta, 2014.

[9] E. Baker, B. B. Trygg, P. Otto, M. Tudor, L. Lynne Ferguson, L Trygg, B Otto, P Tudor, M Ferguson, and L. Ferguson, Project-based Learning Model: Relevant Learning for the 21st Century, no. December. 2004.

[10] A. Prabowo, "Pembelajaran Berbasis Proyek Untuk Meningkatkan Pemahaman Mahasiswa atas Permasalahan Statistika pada Perkuliahan Studi Kasus dan Seminar," J. Kreano, vol. 3, no. 2, 2012. 